\title{
Identification of Temporal Shifting Trends of Submarine Indus Canyon, Pakistan
}

\author{
Gohar Ali Mahar ${ }^{1,2 *}$, Nayyer Alam Zaigham ${ }^{2}$ \\ ${ }^{1}$ Unit for Ain Zubaida Rehabilitation and Groundwater Research, Abdulaziz University, Jeddah, KSA \\ ${ }^{2}$ Federal Urdu University of Arts, Science and Technology, Karachi, Pakistan \\ Email: "goharmahar@gmail.com
}

Received February 1, 2013; revised March 2, 2013; accepted March 31, 2013

Copyright (C) 2013 Gohar Ali Mahar, Nayyer Alam Zaigham. This is an open access article distributed under the Creative Commons Attribution License, which permits unrestricted use, distribution, and reproduction in any medium, provided the original work is properly cited.

\begin{abstract}
Indus Canyon is one of the most prominent sub-aqueous features of the Indus Delta. Indus River, originating from the Manasarovour Lake, hosting at the foot of high Himalayan Mountains Glaciers, forms a huge delta after travelling more than $300 \mathrm{~km}$ at the north eastern coastline of the Arabian Sea. In view to assess the temporal geomorphic change associated with the Indus Canyon, a study has been carried out based on the bathymetric surveyed data compiled in 1895 and satellite data compiled in 1998. The result of the study shows distinct changes in the orientation of the Indus submarine Canyon. Moreover, significant erosional activities have also been identified, associated with the Canyon channel and the channel's walls. Canyon's head has shifted westward rotating about $22^{\circ}$. In addition, the chronological study of the water flow and sediment discharge of the Indus River shows a drastic decline in the flow of river water into the Indus Delta and the sea. This phenomenon appears to modify the fluvial as well as marine dynamics of Indus River consequently affecting the Indus Canyon on a significant scale.
\end{abstract}

Keywords: Indus Canyon; Indus Delta; Indus River System; Erosion; Thalweg; Indus Fan

\section{Introduction}

Literature research study indicates that the reductions in sediment discharge and water flow of delta building rivers under the influence of man-made development activities in the upstream areas have deteriorated the coastal deltaic environment in the tropical and sub-tropical regions of south and south-east Asia i.e., Ganges-Bhurmaputra Delta, Mahanadi Delta, Chao-Pharaya Delta, Changjiang Delta, Huang He delta and Mekong Delta [1-8]. Similarly Indus Delta (Figure 1), which was considered to be the fluvial dominated delta in the past, is currently under stress due to the construction of the water diversion and reservoirs on the river Indus. This phenomenon has affected many features of sub-aerial and sub-aqueous parts of the Indus delta [9].

The presence of fascinating offshore features of Indus Delta/Indus River like Indus Canyon and huge submarine Indus fan indicates that in the historical period Indus River used to carry huge amounts of water loaded with enormous sediments. Presently, neither such a flow of water nor the load of sediments is passing through the

\footnotetext{
${ }^{*}$ Corresponding author.
}

delta region into the Arabian Sea. Such a drastic change in the river flow with sediment is bound to affect the morphology of Indus Canyon which may also depend on the mode of origin of the Canyon.

In fact, Canyons are sub-marine morphological feature, resembling on the valleys' land, curved on the continental shelf [10]. Theories related to the origin of submarine canyons are 1) the idea of diastrophism creating a fault along the incline plain of continental shelf and produces a fault trough or graben between rift blocks and 2) the idea of sub-aerial erosion presented by that submarine canyons which were cut down by the rivers at a time when the land surface was above the sea level [11]. Considering the historical river flow data, the origin of Indus Canyon appears to be associated with erosional activities of the Indus River as diastrophism indicators lack in the area.

For a number of dynamical reasons, under-water submarine canyons can act as conduits, with deep, dense oceanwater moving onto the shelf, or with dense shelf-water cascading to the open ocean, or act as regions of enhanced mixing with focusing and amplification of internal waves [12]. This process supplies direct fresh water 
flow into the deep ocean, balancing the salinity of seawater between the shelf and deep sea.

The Indus Canyon is the dominant feature of the region dissecting the shelf at $20 \mathrm{~m}$ water depth originating about $3.5 \mathrm{~km}$ from the coast [13]. The canyon appears to exhibit a broad meander on the shelf slope [14], which is spectacular erosional and depositional feature [15]. It is also presumed to play a role in preventing the subaqueous delta from developing and funneling sediments towards the Indus submarine fan [16-18]. This paper describes the comparative study related to temporal morphological changes in the general attitudes of Indus sub- marine Canyon and detail analysis of shifting of Canyon head, depositional and erosional trends of Canyon thalweg and flanks. Bathymetric maps generated from the archive map of 1895 and modern data of compiled in 1998 provided a great help to evaluate the temporal geomorphic changes in the Indus submarine canyon (Figure 1).

\section{Indus River and Flow History}

The Indus River came into existence after Eocene period, probably during the late Oligocene [19]. The river ini-
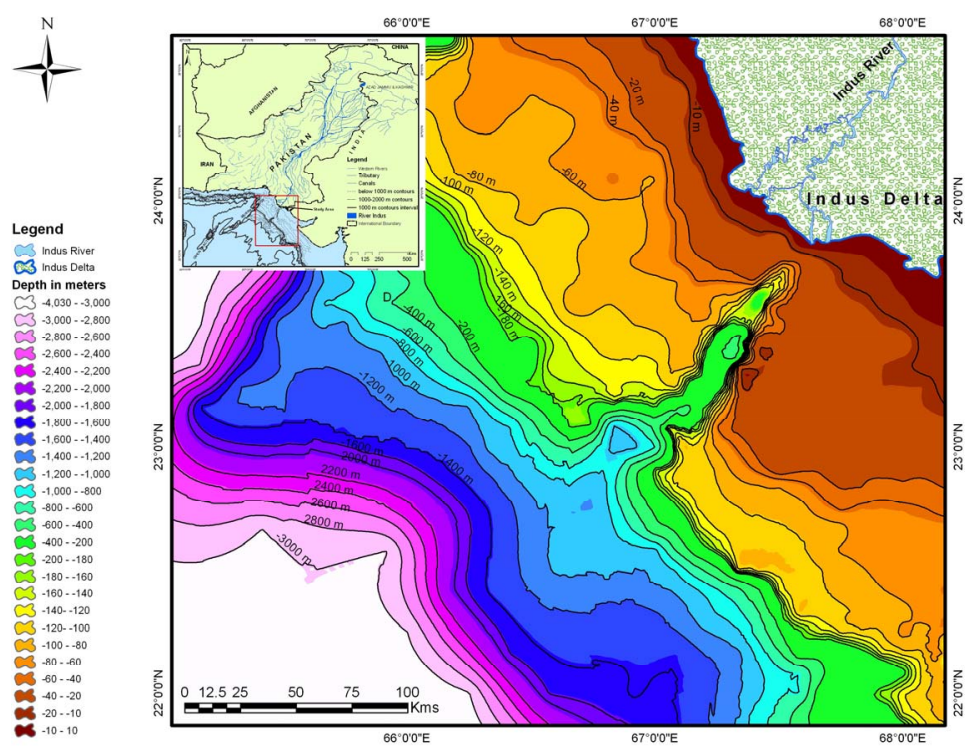

(a)
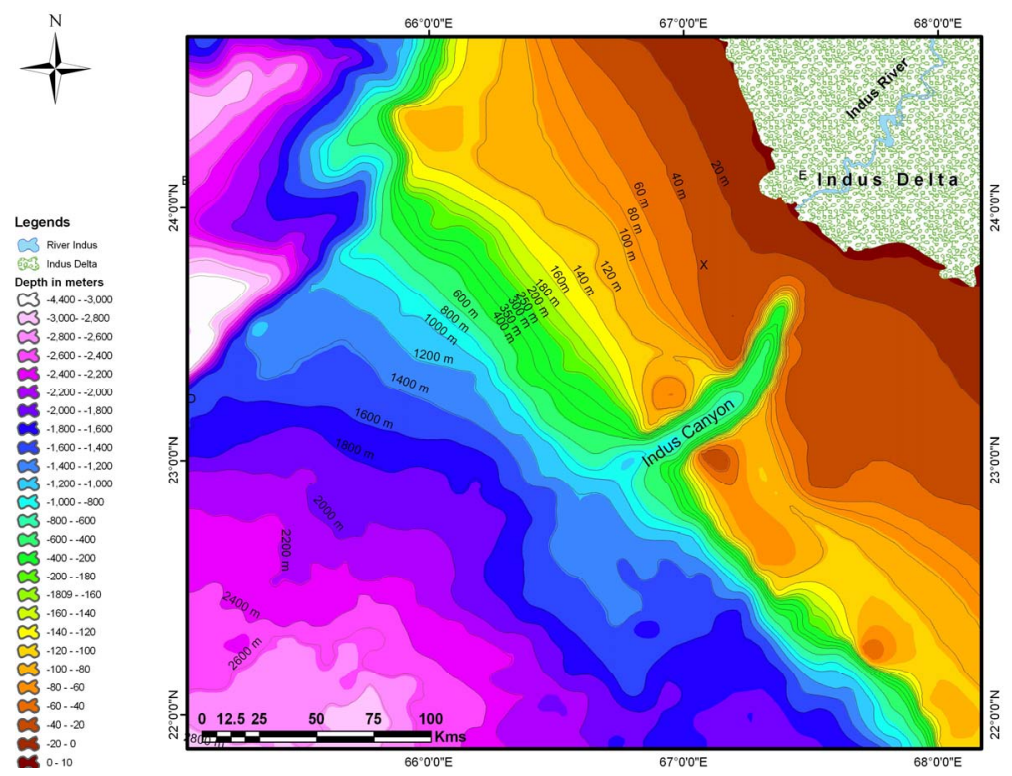

(b)

Figure 1. Bathymetry maps of offshore Indus Delta region and its location map in upper left corner: (a) A map generated by using point data of 1895 (Survey 1895-1896 and published 1924 by Royal Indian Marine); and (b) Generated by using point data of 1995 (compiled in 1998 using satellite with other data and acquired by NOAA, NGDC). 
tially built the delta advancing southward along the Indus trough bordering the Suleiman and Khirthar mountain ranges. During the last 5000 years, the delta migrated southward at the rate of $30 \mathrm{~m} /$ year [20]. Fluvial system and especially sediment supply built the delta and its submarine features like Indus Canyon and Indus Delta extending further southward up to Indian Ocean. The historical record discharge of the Indus River sediment load vary from $675 \mathrm{mt}$ before 1950 (WAPDA letter to Qureshi 1982) to 435 - $440 \mathrm{mt}$ [21] and $300 \mathrm{mt}$ [20]. Personal survey in 2001, 2005 and 2008 of Indus River near Hyderabad city and Thattat city witnessed the dry river course. Personal Communication with Kotri Barrage Authorities in 2005 informed that the supply of sediment from Indus River to Indus Delta is nearly zero and water supply most of the time remained zero in a year and sometimes whole year remain dry. This phenomenon has affected many features of sub-aqueous and submarine delta region.

For last many centuries, the Indus River water has been used for the cultivation and other purposes. As such since then to the present day, the distribution system of water supply has been kept improving time to time in accordance with the ever increasing needs of water to provide better and better food products required for the communities. During 20th century, the significant efforts were made to develop canals from the Indus River System (IRS) particularly for the irrigation purposes. In order to enhance the agricultural activities for the evergrowing needs for food products, the existing irrigation system was greatly expanded with the construction of more barrages, canals \& link-canal networks, and numerous major \& minor dams in the upper and middle parts of the Indus basin. In Pakistan, the water divergent system includes 3 major dams (Terbela, Mangla \& Warsek) numerous smaller dams, 19 barrages, 12 link canals, 45 canal commands and over 107,000 water courses.

The data of water-flow and sediment discharges measured from 1937 to April 2009 and from 1931 to 1987 respectively at the Kotri gauge have been processed, modeled and interpreted (Figure 2). Water-flow data of about 60-years have been studied on annual basis in view to delineate variations in the flow pattern with time. Polynomial curve indicates consistent decline water flow from 1931 to April 2009 to the level of crises threatening the sustainability of the deltaic environment and the coastal ecosystems.

Chronological observation of the Indus Canyon from the end of the 19th century to the end of the 20th century shows a prominent difference in the morphology of the Canyon. This morphodynamic apparently looks naturally displaced by meandering process but its detail analysis shows that this phenomenon is correlated with

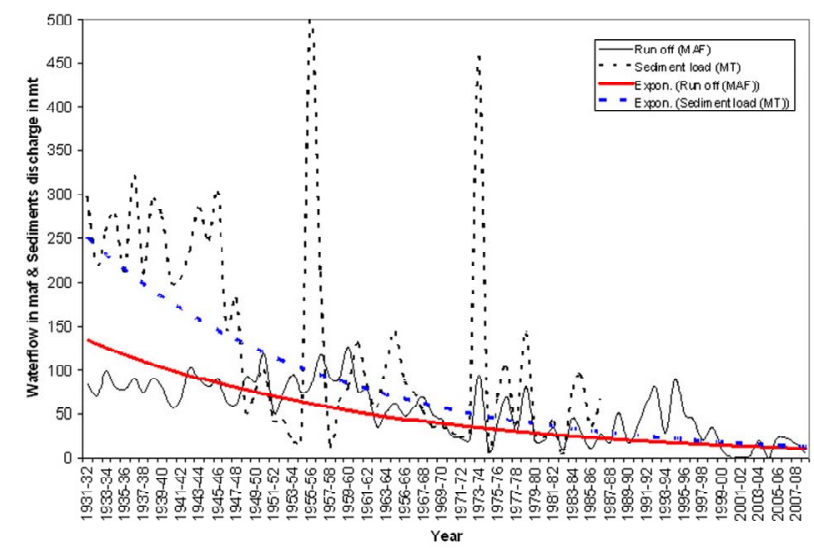

Figure 2. Graphic plot shows the water flow trend from 1931 to April 2009, the sediments discharge trend from 1931 to1987 and the relevant exponential curves till 2009.

the flow of water and sediments in Indus River towards delta. The drastic depletion of water-flow and sediment discharges to the Indus delta, in response of construction of large water divergence canal network, dams, barrages on the IRS and the allocation of three major contributory rivers of IRS to India have created an imbalance in equilibrium between the fluvial and the marine hydrodynamic conditions along the coastal belt which have onset the aggressive sea wave and tidal conditions inviting devastating degradations of the geomorphic features of the Indus Delta.

\section{Methodology}

Main objective of this study is to correlate the historical (1895) with the modern (1998) morphology in the off shore region of the Indus delta. To achieve the purpose of the study two sets of data have been collected, historical map/data, surveyed in 1895-1896 (surveyed and prepared by Indian Royal Marine) from the Hydrographer, Pakistan Navy and the satellite bathymetry data from National Geophysical Data Centre of NOAA site that was compiled in 1998. The contours of the 1895 bathymetric map was manually converted into point data in compareing to the satellite data collected from NGDC that is already in the form of point data so that compatibility could be developed.

Using geostatistical techniques, surfaces incorporating the statistical properties of the collected data have been created. These techniques produce not only prediction surfaces but also error or uncertainty surfaces [22]. For the point data plotted, including Z-value, the interpolation was applied using the Kriging method which is more or less similar to Inverse distance weight (IDW).

Surface interpolation functions as created a continuous (prediction) surface from sampled point values. The continuous surface representation of a raster dataset represents height, concentration, or magnitude [22]. With the 
help of this formula, surface interpolation of the offshore Indus Delta including the Canyon has been generated and converted into contours by using Arc GIS software with varying contours of 20 meter to 200 meters contours interval. Selected cross-section has also been extracted to study the longitudinal and cross-sectional temporal variation associated with Indus Canyon.

\section{Indus Canyon}

Literature, research studies reveal that the submarine canyons are more or less common features on the continental shelf in the front of the delta of significant size. It is also observed that tectonically they are found on both conversion and diversion margins [23-25]. The submarine canyons are generally formed under the influence of various tectonic and/or erosional processes like sub-aerial erosion of upper canyon by fluvial process, erosion by Turbidity currents, Erosion by bottom currents other than turbidity currents. Erosion by slow mass movement of sediments down canyon by creep, progressive slumps, sand fall and lateral redistribution of sediments by deep sea bottom currents are the supporting erosional processes. Drowning by subsidence of valleys cut substantially and up building of canyon walls.

Indus canyon is located in front of the large delta of

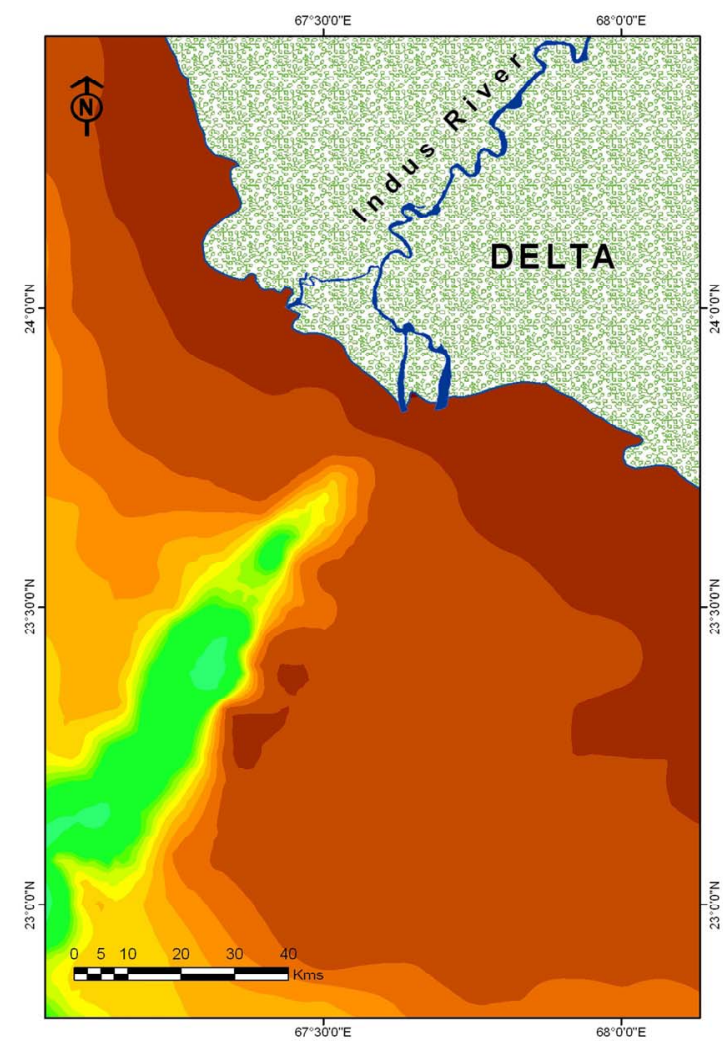

(a) the Indus river, which has presently more or less straight course with few distributaries. The canyon has a continuous seaward slope across the shelf and down the continental slope, very similar to the canyon of the Ganges, Niger and Mississippi deltas.

The correlation bathymetry maps of 1895 and 1998 shows major geomorphic changes associated with the following features (Figure 3):

1) Head of the Canyon;

2) Channel slope (thalwag) of the Canyon;

3) Thalweg of Indus Canyon;

4) Flanks of the Canyon.

\subsection{Head of the Indus Canyon}

In view to study the general attitude of the canyon head, the depth contour of $40 \mathrm{~m}$ is selected for the present study which shows prominent relief of the head at the available scale of map (Figure 4).

The bathymetric contour of 1895 shows the location of the canyon head at latitude $23.746568 \mathrm{~N}$ and longitude $67.746568 \mathrm{E}$ at a distance of $12 \mathrm{~km}$ from the coastline. The orientation of the canyon head is found in northeast-southwest direction.

On the other hand, the $40 \mathrm{~m}$ depth contour of 1998 bathymetry map shows the location of the Canyon at

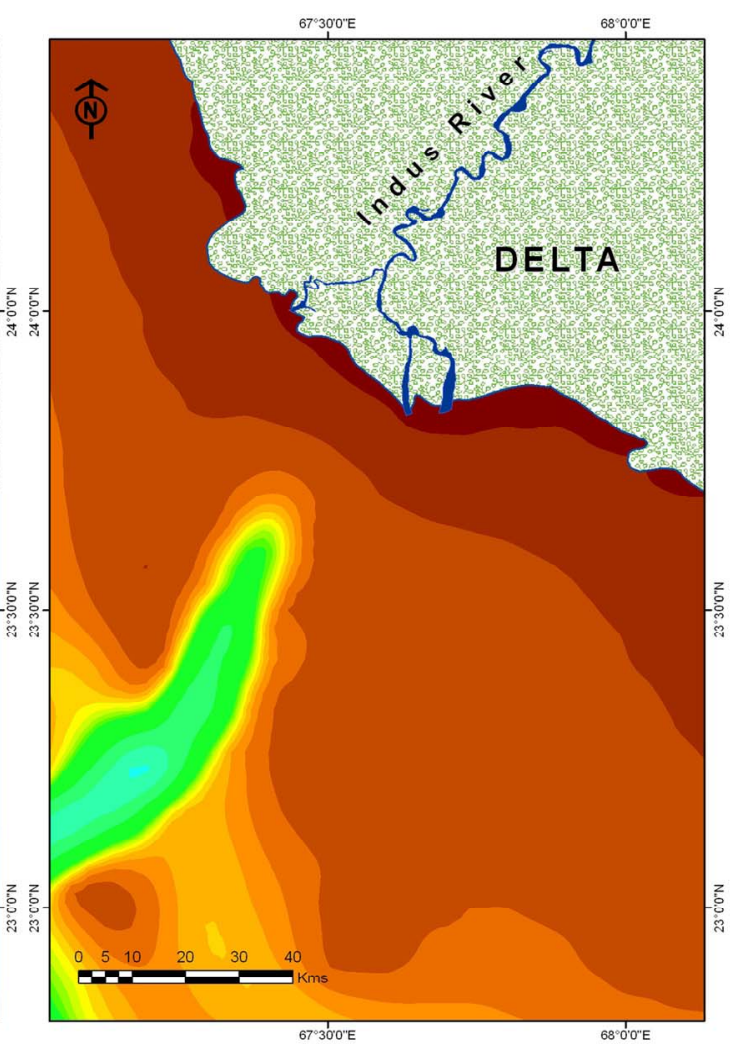

(b)

Figure 3. Maps of 1895 (a) and 1998 (b) show the relative morphologic changes in the attitude of the Indus Canyon with respect to the time and space. 


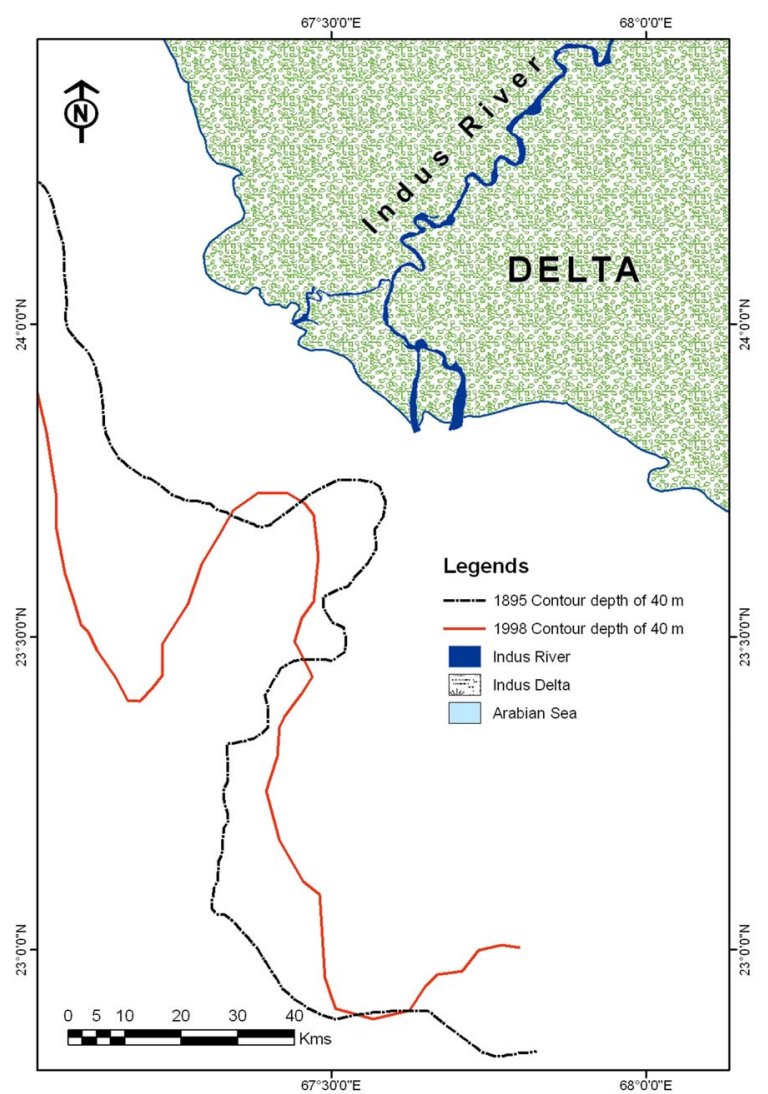

Figure 4. Map shows the Indus Canyon configuration during 1895 and 1998 at the depth of $40 \mathrm{~m}$ contours. The correlation of canyon axis of 1895 and 1998 reveals the westward shift of canyon mouth.

latitude $23.732075 \mathrm{~N}$ and longitude $67.427861 \mathrm{E}$ at the distance of $24 \mathrm{~km}$ from the coastline. Moreover, the strike of the axis has now changed from $\mathrm{N} 52^{\circ} \mathrm{E}$ to $\mathrm{N} 74^{\circ}$ E. The changed location of the head shows a westward shift of $15 \mathrm{~km}$. From this correlative study, it is inferred that the head of the Indus Canyon has shifted westward, receded seaward and tilted counterclockwise as well.

During the 19th century, the mouth of the Indus River had only two main distributaries, Sata and Ochito which were remained visible in flowing condition [26]. These distributaries have been completely disappeared at the end of the last century. Moreover, the satellite data from the period of 1978 to 2007 also supports the change of the mouth of river course [9]. It suggests that the changes in the attitude of the canyon head are associated with the westward shifting of Indus River course within the delta region.

Seaward receding of the canyon head is inferred to occur under the influence of decreasing intensity trend of Indus River water-flow and sediment discharge. As the Indus River water has been checked and/or diverted in the upstream region, since last more than one and half century, the fluvial turbidity currents weakened, resulting in the transformation of erosional activities. Consequent- ly, intense varying episodes of cut and fill occurred in the shelf area between delta and canyon head.

\subsection{Channel Slope of the Indus Canyon}

As evident from the fact that before the inception of the water diversion since 1860 in the upstream region, the delta used to have about 150 MAF of water [17,27-29] enough to maintain erosional activities within the canyon head close to the delta coastline. In view to study the variation in morphological characteristics of the main canyon channel with respect to the time difference of about 100 years, the longitudinal sections of bathymetric profiles of 1895-1896 and 1998 have been overlaid on each other (Figure 5(a)).

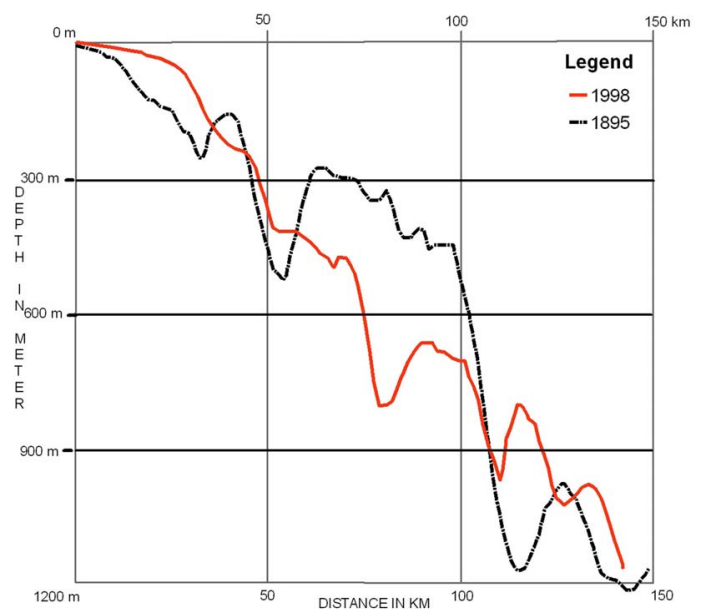

(a)

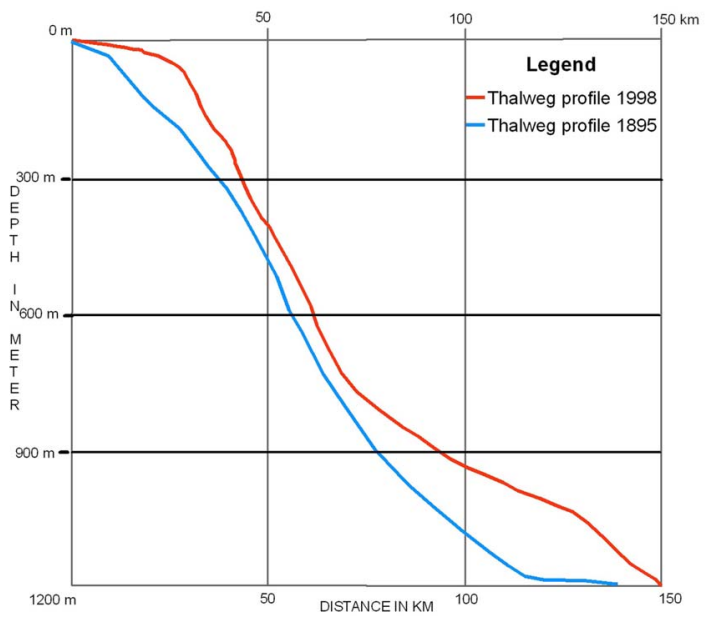

(b)

Figure 5. The correlation study of the longitudinal sections of Indus Canyon (a) showing the sediment terraces deposited in the channel as encountered on bathymetry map of 1895 and 1998. Deeper inflexions represent the intersectional point of the thalweg crossing across the longitudinal section; (b) shows only the slope trends by omitting the intervening sediment terraces with respect to the bathymetric data of 1895 \& 1998. 
The submerged bathymetric trend of the canyon head near the coastline shows the fact that up to 1895 , the mouth of the Indus River and the head of the Indus Canyon were almost together. The Indus river water with sediment load used to flow continuously into the Indus Canyon with the significant discharge pressure. At that time erosional activities in the near shelf area seems to be relatively intensive almost from coastline down to $20 \mathrm{~km}$ into the sea. In this part, the slope has been estimated as $2.5 \mathrm{~m} / \mathrm{km}$ and $6.25 \mathrm{~m} / \mathrm{km}$ at the distance of $10 \mathrm{~km}$ and 20 $\mathrm{km}$, respectively.

The terrace formation seems to occur from $20 \mathrm{~km}$ down to $150 \mathrm{~km}$ into the sea. It is observed that the elevation of the terraces increases with depth particularly between $50 \mathrm{~km}$ and $110 \mathrm{~km}$ from the delta. The section shows that north coast escarpment slope of the sediment terraces are relatively steeper than the south western escarpment slope, indicating the presence of relatively steeper thalweg gradient.

On the other hand, the longitudinal profile developed on the satellite bathymetric data of 1998 shows entirely changed morphological features associated with the canyon channel during the period of about 100 years (from 1895 to 1998). Present shelf area shows sediment deposition in near shore area that has developed the shallow shelf region. Moreover, the shelf has also been extended up to $25 \mathrm{~km}$ and at the depth of $40 \mathrm{~m}$ from where active expression of the head of the canyon now starts. This profile shows the presence of terrace development at 40 $\mathrm{km}$ distance from delta. The terraces are seen down to $150 \mathrm{~km}$ into the sea from coastline.

The correlation between profile-1895 and profile-1998 shows the distinct geomorphic variations within the Indus Canyon channel right from delta region deep into the sea up to $150 \mathrm{~km}$ of distance. Near the delta region, shelf area is observed to be comparatively shallow and extended with respect from historical data. Sediment terraces and meanders of the channel are seems to be eroded and modified. Moreover, gradient of the Thalweg also modified.

\subsection{Thalweg of the Indus Canyon}

In view to study geomorphic change with respect to thalweg of the Indus Canyon, the longitudinal profiles have been developed by using bathymetric data of 1895 and 1998 periods (Figure 5(b)). The terraces along these profiles have been reduced to avoid interpretational complexity.

The profile shows significant geomorphic changes along the thalweg. The most prominent change is the significant thick deposition of the sediments all along the thalweg of 1998 right from deltaic area down into the deep sea with respect to thalweg of 1895 . The thickening of the thalweg is more or less sub-parallel except some erosional variations. The shelf break on the profile-1895 is at $10 \mathrm{~km}$ from delta at the depth of $25 \mathrm{~m}$, whereas the shelf break along the profile-1998 is shifted at the distance of $22 \mathrm{~km}$ from the delta but at the same distance the thalweg of profile- 1895 was at $200 \mathrm{~m}$. The apparent thickness of the deposited sediments now is found about $175 \mathrm{~m}$ (true thickness may be about $100 \mathrm{~m}$ ). Similarly, at the mid slope of both the profiles about $50 \mathrm{~km}$ from delta, the water depths are found at $400 \mathrm{~m}$ on profile-1998 and at $510 \mathrm{~m}$ on profile-1895 with apparent thickness of 110 (true thickness $75 \mathrm{~m}$ approx). At the distance of $100 \mathrm{~km}$ from delta, the water depth down to thalweg encounters at $925 \mathrm{~m}$ on profile- 1985 and at $1050 \mathrm{~m}$ on profile- 1895 with apparent depth variation of $125 \mathrm{~m}$ (true thickness may be about $100 \mathrm{~m}$ ).

The above observation shows that during a period of about 100 years from 1895-1998 the analyses of bathymetric data of both the periods reveal that the enormous amount of sediments has been deposited all along the thalweg which seems to correspond with the observation made regarding the erosional process of sediment terraces of the Indus Canyon in earlier section.

\subsection{Walls of the Indus Canyon}

The comparative study of profile-1895 and profile-1998 of the eastern flank shows that the continental shelf is not much affected than the continental slope (Figure 6(a)). Minor accretion is observed near the delta coastline on profile-1998, otherwise the shelf shows consistent low gradient of the shelf extending about $60 \mathrm{~km}$ from the delta on both the profiles. The profiles-1895 shows extension of the shelf up to about $120 \mathrm{~km}$ from the coast with gentle stepping/terracing pattern. On the other hand, the profile-1998 shows significant accretion at the shelf break and causing sinoidal pattern instead of gentle terracing behavior as observed on profile-1895. The position of the shelf break has been shifted from a distance of $120 \mathrm{~km}$ to $100 \mathrm{~km}$ from the delta that is $20 \mathrm{~km}$ northward or landward. There is a significant depth-wise shift of shelf break from $128.5 \mathrm{~m}$ on profile-1895 to $35 \mathrm{~m}$ on profile-1998, which is relative shift of $93.5 \mathrm{~m}$ within 100 years towards the surface of sea level.

The comparative study of both the profiles shows a remarkable continuous northward parallel migration continental slope. Considering the reference point " $A$ " on profile-1998 and " A' " on profile 1895 lying at the depth of $530 \mathrm{~m}$, the shift of the continental slope is calculated about $16 \mathrm{~km}$ which indicate the erosion of $39 \mathrm{~km}$ thick slab of sediment all along the slope.

Comparison of profile-1895 and profile-1998 drawn on the western flank of the Indus Canyon shows an intense variability between both the profiles along the shelf as well as shelf slope (Figure 6(b)). The profile-1998 shows dominant accretion phenomena right from delta coastline to the shelf break in comparison to profile-1895. 
Profile-1895 shows a consistent increase of slope of the shelf right up to shelf break. The shelf shows a number of gentle terracing behaviors. On the other hand, profile-1998 shows a shallowness of the shelf up to about 50 $\mathrm{km}$ from the delta and onward it shows sinoidal pattern up to shelf break. The profile-1895 shows a shelf break at $117 \mathrm{~km}$ away from the coastline whereas the profile 1998 shows the shelf at about $89 \mathrm{~km}$ away from the coastline. Like the eastern flank, the western also shows northward shift of about $28 \mathrm{~km}$. The depth of the shelf break has also changed from $187.5 \mathrm{~m}$ on profile-1895 to $107 \mathrm{~m}$ on profile-1998.

The shelf slope shows northward shift, but the behavior is about consistently parallel like in case the easternflank of the canyon. Lower part of the shelf slope shows parallel shifting at the mean depth of $817 \mathrm{~m}$ from $33 \mathrm{~km}$ on profile-1895 to $21 \mathrm{~km}$ on profile-1998 (i.e., a total

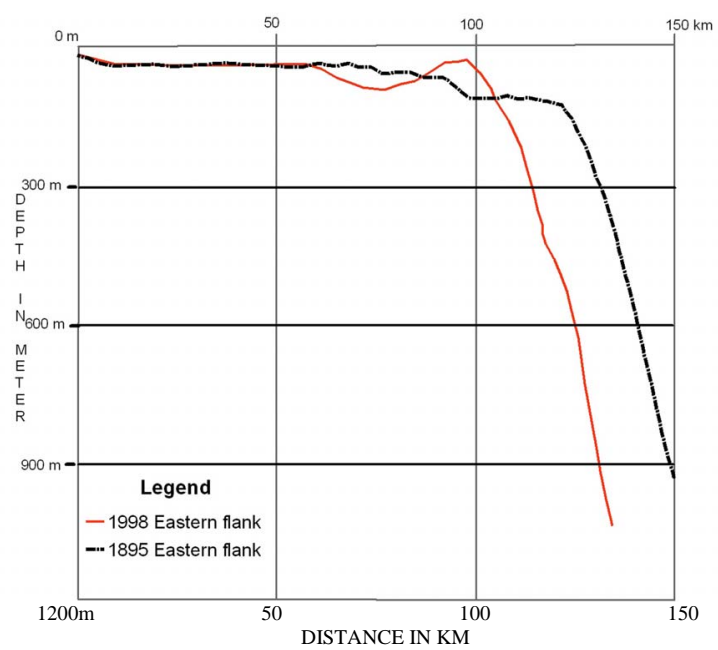

(a)

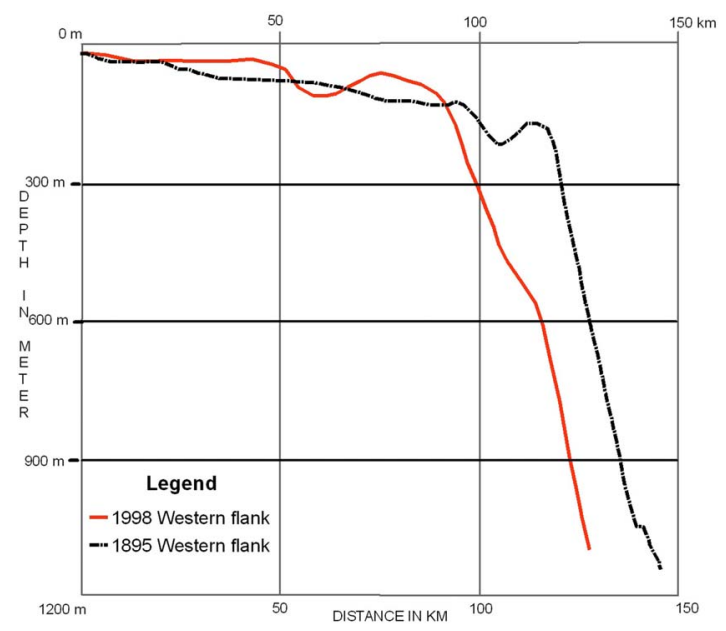

(b)

Figure 6. Longitudinal sections of the eastern (Map a) and western (Map b) flank of the Indus Canyon show the correlation between the trends of shelf and slope derived from the bathymetry data of 1895 \& 1998 . variation of $12 \mathrm{~km}$ approximate). On the other hand, the upper part of the shelf slope shows a larger amount of shifting at the average depth of $313 \mathrm{~m}$ from $120 \mathrm{~km}$ on profile-1895 to $100 \mathrm{~km}$ on profile-1998 (a total shift of $20 \mathrm{~km})$.

Comparing the degree of variation occurred in 100 years from 1895 to 1998 between the eastern and western flanks, it is inferred that the western flank of the canyon has gone under intense erosional and depositional activities, most probably under the hydrodynamics imbalances between fresh water and sea water regime.

\section{Discussion}

Before the construction of water of reservoir and canals in the upstream part of the river under the natural flow conditions, enormous amount of water and sediments poured into the sea were the cause formation of Indus Canyon and fan and other natural submarine features. Indus Canyon, which is a prominent morphological feature of sub-aqueous Indus delta, is under the process of frequent morphodynamics in the last century. Water divergent activities on IRS in the last century stopped the water flow and sediment discharge in the Deltaic region. Despite the fact that the water divergent system and the reservoirs built on the Indus River System included many major dams, barrages, canals have deteriorated the downstream deltaic part, more reservoir structures have also been and are being constructed on Indus River System by India and Pakistan causing enormous decrease of Indus water to Pakistan.

The morphological change analysis of the Indus canyon, especially on the head of the canyon and the integration of analytical results of longitudinal and crosssectional profiles and the profiles of the canyon walls indicate the onset of more active hydrodynamic activities relevant to Indus delta in general and geomorphic changes of different features of Indus Canyon in particular. These sub-surface morphodynamics are coordinated by mouth of the river, where meandering process and morphological changes are very frequent particularly in last century. It looks apparently a natural process but is being controlled by manmade activities by the control on the Indus River System.

\section{Conclusion}

Distinct changes are revealed at the location of head and axis of the Indus submarine canyon in addition to the erosional activities associated with its channel and the channel's walls. Canyon's head has shifted 15 km westward rotating from $\mathrm{N} 52^{\circ} \mathrm{E}$ (in 1895) to $\mathrm{N} 74^{\circ} \mathrm{E}$ (in 1998). Erosion of sediment terraces has modified the course and thalweg of the canyon. The lateral flanks on both sides of the canyon have significantly been eroded parallel to the 
shelf slope. These changes are linked with the quantity and pattern of the water flow and sediment discharge at the mouth of the river. Change in the pattern and negligible quantity of the water flow and sediment discharge into the sea has deteriorated the natural shape of the Indus Canyon. It is speculated that under the same conditions of environmental flow, this natural feature in future will be more deformed.

\section{Acknowledgements}

1) We are thankful to Hydrographers, Pakistan Navy, Government of Pakistan, for the generous cooperation in providing the historical bathymetry charts of Sindh Coastline;

2) We are thankful to National Geophysical Data Centre (NGDC) of National Oceanic and Atmospheric Administration (NOAA) for providing the gridded global relief data of the study area through their web site: www.ngdc.noaa.gov;

3) HEC, Pakistan is gratefully acknowledged for encouraging the research work, facilitating for data availability.

\section{REFERENCES}

[1] Z. Yang and H. Wang, "The Coast of China," In: N. Mimura, Ed., Asia-Pacific Coasts and Their Management, The States of Environment. Coastal Systems and Continental Margins, Springer, Berlin, 2008, pp. 65-171.

[2] S. L. Yang, M. Li, S. B. Dai, J. Zhang and P. X. Ding, "Drastic Decrease in Sediment Supply from the Yangtze River and Its Challenge to Coastal Wetland Management," Geophysical Research Letters, Vol. 33, 2006, Article ID: L06408. doi:10.1029/2005GL025507

[3] S. Vongvisessomjai, R. Polsi, C. Manotham, D. Srisaengthong and S. Charulukkana, "Coastal Erosion in the Gulf of Thailand,” In: J. D. Milliman and B. U. Haq, Eds., SeaLevel Rise and Coastal Subsidence, Kluwer, Dordrecht. 1996, pp. 131-150. doi:10.1007/978-94-015-8719-8_7

[4] S. Rokugawa, H. Suzuki, Y. Kazama and Y. Okubo, "Consideration on Management of Coastal Environment at Deltas in Thailand,” Research Report, UOT/AISt- CCOPDMR/DMCR Joint Program, CCOP Technical Secretariat, Bangkok, 2006.

[5] J. M. Coleman, O. K. Huh and D. Braud Jr., "Wetland Loss in World Deltas," Coastal Studies Institute, Louisiana State University, Baton Rouge, 2006.

[6] H. J. Wang, Z. S. Yang, Y. Saito, J. P. Liu, X. X. Sun and Y. Wang, "Stepwise Decrease of the Huanghe (Yellow River) Sediment Load (1950-2005): Impacts of Climate Change and Human Activities," Global and Planetary Change, Vol. 57, No. 3-4, 2007, pp. 331-354. doi:10.1016/j.gloplacha.2007.01.003

[7] M. Mohanti and M. R. Swain, "Mahanadi River Delta, East Coast of India: An Overview of Evolution and Dynamic Process,” 2004.
[8] K. O. T. Thi, L. N. Van, T. Massaki, L. Kobayashib, S. Tanabeb and Y. Saitoc, "Holocene Delta Evolution and Sediment Discharge of the Mekong River Southern Vietnam,” Quaternary Science Review, Vol. 21, No. 16, 2002, pp. 1807-1819. doi:10.1016/S0277-3791(02)00007-0

[9] G. A. Mahar and N. A. Zaigham, "Geomorphic Degradation of Indus Delta and Its Demographic Impact,” Ph.D. Thesis, University of Karachi, Karachi, 2010.

[10] R. C. Sharma and M. Vatal, "Oceaneography for Geographer,” Chaitanya Publishing House, Allahabad, 1986.

[11] F. P. Shepard and K. O. Emery, "Submarine Topography off the California Coast: Canyon and Tectonic Interpretation,” Geological Society of America Special Paper, Vol. 31, 1941, pp. 1-171.

[12] S. E. Allen and X. D. de Madron, “A Review of the Role of Submarine Canyons in Deep-Ocean Exchange with the Shelf,” Water Science, Vol. 5, No. 4, 2009, pp. 607-620.

[13] L. Giosan, S. Constantinerscu, P. D. Clift, Tabrez, M. Danish and A. Inam, "Recent Morphodynamics of the Indus Delta Shore and Shelf,” Continental Shelf Research, Vol. 26, 2006, pp. 1668-1684. doi:10.1016/j.csr.2006.05.009

[14] F. Coumes and V. Kolla, "Deltaic Morphology and Sedimentology with Special Reference to the Indus River Delta," In: Marine Geology and Oceanography of Arabian Sea and Coastal Pakistan, Van Nostrand Reinhold, New York, 1984, pp. 101-110.

[15] R. U. Von and M. Tahir, "Late Quaternary Sedimentation on the Upper Indus Shelf and Slope (Pakistan): Evidence from High Resolution Seismic Data and Coring,” Marine Geology, Vol. 138, No. 3-4, 1997, pp. 193-236. doi:10.1016/S0025-3227(96)00090-4

[16] R. R. Nair, N. H. Hashimi and V. P. Rao, "On the PossiBility of High Velocity Tidal Streams as Barriers to Long Shore Sediment Transport: Evidence from the Continental Shelf off the Gulf of Kutch, India,” Marine Geology, Vol. 3, 1982, pp. 11-427.

[17] S. R. Islam, “The Indus Submarine Canyon,” Pakistan Geographical Review, Vol. 14, 1959, pp. 32-34.

[18] J. T. Well and J. M. Coleman, "Deltaic Morphology and Sedimentology, with Special Reference to the Indus River Delta: Marine Geology and Oceanography of Arabian Sea and Coastal Pakistan,” Van Nostrand Reinhold, New York, 1984.

[19] E. O. Waser, "Sedimentological Aspects of Strata Encounter on Leg 23 in Northern Arabian Sea," Initial Reports of DSDP, US Government Printing Office, Washington DC, 1974, pp. 503-529.

[20] A. H. Kazmi, “Geology of the Indus Delta,” In: B. U. Haque and J. D. Milliman, Eds., Marine Geology and Oceanography of Arabian Sea and Coastal Pakistan, Van Nostrand Reindhold, New York, 1984, pp. 71-84.

[21] J. N. Holeman, "Sediment Yield of Major Rivers of the World,” Water Resource Research, Vol. 4, No. 4, 1968, pp. 737-747. doi:10.1029/WR004i004p00737

[22] Environmental System Research Institute (ESRI), Redlands, 1999-2008.

[23] G. F. Thorpe, “The Submarine Cañons of the Ganges and 
Indus. Blackwell Publishing,” The Geographical Journal, The Royal Geographical Society, Vol. 26, No. 5, 1905, pp. 568-571.

[24] S. R. Islam, “The Indus Submarine Canyon,” Pakistan Geographical Review, Vol. 14, 1959. pp. 32-34.

[25] P. Clift, G. Christoph, E. Rosemary, L. Jae, H. Peter, S. Amjad, S. Robert and S. Hans-Ulrich, "The Stratigraphic Evolution of the Indus Fan and the History of Sedimentation in the Arabian Sea," Marine Geophysical Research, Vol. 23, No. 3, 2002, pp. 223-245. doi:10.1023/A:1023627123093

[26] M. R., Haig, A. S. M. Robert, “The Indus Delta Country: A Memoir, Chiefly on Its Ancient Geography and History," Vol. 6, 1894, 148 p.

[27] J. D. Milliman, G. S. Qureshee and M. A. A. Beg, "Sedi- ment Discharge from the Indus River to the Ocean: Past, Present and Future,” In: Marine Geology and Oceanography of Arabian Sea and Coastal Pakistan, Van Nostrand Reinhold, New York, 1984, pp. 65-84.

[28] J. M. Coleman and O. K. Huh, "Major World Deltas: A Perspective from Space,” Research Report Submitted to NASA, Coastal Studies Institute, Louisiana State University, Baton Rouge, 2003.

[29] V. I. Kravtsova, V. N. Mikhailov and N. A. Efremova, "Variations of the Hydrological Regime, Morphological Structure, and Landscapes of the Indus River Delta (Pakistan) under the Effect of Large-Scale Water Management Measures,” Water Resources, Vol. 36, No. 4, 2009, pp. 365-379. 